\title{
Do Different Instruction Modalities Matter? Exploring the Influence of Concept Mapping and Translation Strategies Instruction on the Reading Comprehension Ability of Adult EFL Learners
}

\author{
Mehran Davaribina \\ Department of English Language, Ardabil Branch, Islamic Azad University, Ardabil, Iran \\ Shahram Esfandiari Asl \\ Department of English Language, Ardabil Branch, Islamic Azad University, Ardabil, Iran
}

\begin{abstract}
The present study was an attempt to compare the effect of concept mapping strategy instruction and translation strategy instruction on the reading comprehension ability of the Iranian EFL learners. To do so, 90 EFL learners at the intermediate level studying in a language institute in Ardabil, north Iran were randomly assigned into three equal groups (concept map, translation and control). Having taken a reading pretest, the participants in experimental groups were instructed using mentioned strategies whereas the control group learners were taught the same content with no strategies integrated. Results of analysis of covariance (ANCOVA) revealed that the participants in the experimental groups significantly outperformed the participants in the control group, suggesting that the application of concept mapping and translation strategy training can generate more positive effect on the reading comprehension ability of the learners. Also, the findings of the study indicated that the concept mapping group outperformed the translation strategy group on the reading posttest. Pedagogical implications and suggestions of the study will be discussed.
\end{abstract}

Index Terms-concept mapping strategy, strategy-based instruction, translation strategy, reading comprehension, EFL learners

\section{INTRODUCTION}

Reading comprehension is the most significant source of information access in an EFL situation (Crystal, 1996). As Swalander and Taube (2007) maintain "good reading ability is the key to success in educational settings and this is why researchers try to find effective educational and psychological variables that can explain variations in reading ability and academic achievement" (p. 207). The literature on reading comprehension skill abounds studies which aim at integrating different teaching modalities to enhance the comprehension ability of EFL learners. Strategies-based instruction (SBI), in which learners get familiarize with techniques and procedures to facilitate making sense out of a text, is now widely assumed to boost the reading ability of second language learners. Antoniou and Souvignier (2007, p. 43) maintain that "effective reading requires the use of strategies that are explicitly taught". It could be argued that learners are most successful when their instructors employ different strategies to help them read and write challenging texts.

Although numerous studies have investigated and categorized the types of learning strategies employed by efficient language learners, 'there have been fewer studies focusing on the second goal of trying to teach language learning strategies in classroom settings (Chamot, 2005). One such strategy, which has attracted the reading researchers' attention, is concept mapping. In fact, the effect of concept mapping strategy instruction on the reading comprehension ability of the EFL learners has been the home of choice for ELT researchers since1980s (Talebinejad\& Mousapour Negari, 2007). The positive effect of concept mapping instruction on different educational outcomes has been shown by many studies (Chularut\& DeBacker, 2004; Liu, Chen \& Chang, 2010; Ojima, 2006; Snead \& Wanda, 2004). There are, however, few studies investigating the effect of concept mapping on reading comprehension of EFL learners.

In a study by Chularut and DeBacker (2004), the effect of concept mapping on academic achievement, self-efficacy, and self-regulation of students in English classes as a second language was investigated. The subjects of the study were college and high school students, who enrolled for English classes. The findings of the study showed that the group of students who used concept mapping achieved higher scores in English achievement, self-efficacy, and self-regulation in comparison to control group(as cited in Salehi, Jahandar, \& Khodabandehlou, 2013).

Vakilifard and Armand (2006) studied the effect of concept map on French (as L2) reading comprehension. The findings of this study showed that the experimental group did better in reading comprehension in comparison to control group. 
Moreira and Moreira (2011) used concept mapping in a research in foreign language class as an instrument for context comprehension of course books and achieving meaningful learning. The findings of the study showed that concept mapping can effectively lead to meaningful learning and students got self-confidence in transferring the concept to new situations.

Moreover, translation has often been classified as one of the cognitive learning strategies (Chamot, 1987; Chamot\& Kupper, 1989; Chamot et al., 1987; O’Malley et al., 1985a; O’Malley et al., 1985b; Oxford, 1990). Chamot (2005) argues that translation could be considered a learning strategy and can affect quality and process of composing essays by the learners. Gómez, López and Marin, (2011) also consider translation as a learning strategy which reduces the learners' stress in reading comprehension activities.

Bassnett (1998) believed that "translation offers a crucial lesson in how to read, since it is a critical way into the text." She saw it as an effective means of forcing students to read texts thoughtfully and to concentrate on the lexical, grammatical and textual levels, and improving general knowledge, while "unveiling students' problems in comprehending (English) texts" (Brini, 2000, p.?). Translation can be a useful tool to analyze comprehension pitfalls, which may lead to problems in discourse processing (Abdrabou, 2003).With respect to empirical studies, Hsieh (2000) found that translation benefited Taiwanese students' English reading in terms of increasing their reading comprehension, reading strategies use, vocabulary learning, and cultural background knowledge. Liao (2006) conducted both quantitative and qualitative surveys on 351 Taiwanese students on their belief about translation. Liao reported participants as believing that translation helped them acquire English language skills like reading, writing, speaking, vocabulary, idioms, and phrases.

Recently, there have been many attempts and researches for improving the situation of learning/teaching English in Iran. However, as Jalilifar (2010) points out, "despite the growing interest in learning English as a foreign language in Iran, students at the college level seem rarely proficient enough to read and comprehend English language texts" (p.98). Due to Iranian learners' problems in comprehending texts, many of them loose their interest in reading English texts and this could lead to their failure in academic English courses. As such, "finding an efficient approach which facilitates learners' learning and helps them comprehend better seems to be quite necessary" (p. 98) (as quoted by Khajavi \& Ketabi, 2012).

The present study was motivated by the above mentioned researches on the importance of teaching language learning strategies. More specifically, we intended to see if explicit teaching of "concept mapping" and "translation" strategies. Can pave the way and help the learners better decode the texts. The two mentioned strategies were selected on the assumption that the translation strategy is constantly used in Iranian EFL classes and concept mapping strategy would be a cogent strategy to help foreign language learners sum up English passages and easily appreciate what the gist of reading materials are.

Considering the purpose of the study, the following research questions were formulated.

R.Q.1 Does concept mapping strategy improve reading comprehension ability of Iranian EFL learners?

R.Q.2 Does translation strategy improve reading comprehension ability of the Iranian EFL learners?

R.Q.3 Is reading comprehension ability of the EFL learners differently improved through the concept mapping and translation strategies?

Considering the research questions mentioned above, the following null hypotheses were presented:

H01. Concept mapping strategy does not improve reading comprehension ability of Iranian EFL learners.

H02. Translation strategy does not improve reading comprehension ability of the Iranian EFL learners.

H03. Reading comprehension ability of the EFL learners is not differently improved through the concept mapping and translation strategies.

\section{METHOdOLOGY}

\section{A. Participants}

The participants of the study were 90 intermediate level male and female students with the age range 18 to 25 in a language institute in Ardabil, Iran. These participants were chosen from a pool of 150 students according to their performance in a sample NELSON proficiency test.

\section{B. Instrumentation}

The data for the present study were collected by means of two tests as follows: a NELSON test and a validated researcher-made reading comprehension test which was used as both pre-test and post-test of reading comprehension development.

Based on the scores, 90 students whose scores fell within one standard deviation above and below the mean (19.83 \pm 4.29) were selected as the main participants.

The second instrument was a test of reading comprehension (selected from among the reading tests presented in the test manual of the learners' course book). The test was piloted with30 similar students. The result is represented in Table 2.2. The reliability of the test was 0.83 as measured by KR-21 method. This test served as the post-treatment reading comprehension measure. 


\section{Procedure}

To begin with, Nelson proficiency test was administered and, as mentioned above 90 intermediate learners were randomly divided into three groups. As the treatment in the first experimental group were instructed how to use concept mapping strategies to do reading comprehension tasks. More specifically, the learners were introduced to the nature of concept map as "a special form of a web diagram for exploring knowledge and gathering and sharing information" (Shimerda, 2007, p.118).Then they were asked to employ the five steps of concept mapping strategy on the reading materials. The steps were selected based on Yağmurşahin (2013, p.590).

In the second experimental group, the participants were asked to focus on translation strategies while doing reading comprehension. The learners in this group were expected to translate the given passages prior to answering the comprehension questions or analyzing the texts. The strategies they used were obtained from O'Brien (2011), who considers "translation strategies as basis for cognitive explorations" (p.23) and introduces translation strategies such as equation, substitution, divergence, convergence, amplification, reduction, diffusion, condensation, and reordering.

The learners in the control group did not receive any specific training on the concept mapping or translation strategy trainings; however, they went through the same passages and comprehension questions with the teacher explaining the meaning of unknown words and asking the learners to read aloud as well as paraphrase difficult sentences.. The treatment sessions lasted for 20 sessions and learners in all groups sat the posttest of the study immediately after the last session.

\section{DATA ANAlyses AND RESUlts}

As mentioned above NELSON test was administered to the original pool of the participants to select the intermediate level learners. Table I below shows descriptive statistics for the participants' performance on this test.

TABLE I.

DESCRIPTIVE STATISTICS FOR THE SCORES ON NELSON TEST

\begin{tabular}{|c|c|c|c|c|c|c|}
\hline & $\mathrm{N}$ & Range & Minimum & Maximum & Mean & SD \\
\hline NELSON & 150 & 6.0 & 17.0 & 23.0 & 25.44 & 4.294 \\
\hline
\end{tabular}

Following the proficiency measure, the participating groups sat the pretest of the study. Table II below represents the descriptive statistics for the scores on this test.

TABLE II.

DESCRIPTIVE STATISTICS FOR THE SCORES ON PRE-TEST

\begin{tabular}{lllll}
\hline & $\mathrm{N}$ & Mean & Std. Deviation & Std. Error \\
\hline Translation & 30 & 25.00 & 1.414 & .258 \\
Concept Mapping & 30 & 23.07 & 1.363 & .249 \\
Control & 30 & 26.07 & 1.363 & .249
\end{tabular}

Once the treatment sessions were over, the participants took the posttest of the study. Table III shows descriptive statistics for the groups' performance on this test.

TABLE III.

DESCRIPTIVE STATISTICS FOR SCORES ON POST-TEST

\begin{tabular}{lllll}
\hline \multirow{2}{*}{ Group } & \multirow{2}{*}{ Mean } & \multirow{2}{*}{ Std. Error } & \multicolumn{2}{l}{$95 \%$ Confidence Interval } \\
\cline { 5 - 5 } & & & Lower Bound & Upper Bound \\
\hline Translation & 16.877 & .141 & 16.596 & 17.158 \\
Concept Mapping & 20.532 & .135 & 20.265 & 20.800 \\
Control & 15.942 & .132 & 15.680 & 16.203 \\
\hline
\end{tabular}

An analysis of covariance (ANCOVA) was run to compare the means of the three groups on the post-test of reading comprehension while controlling for possible differences between their entry reading ability. Before running the analysis it was necessary to make sure that the assumptions associated with ANCOVA were met.

\section{A. Assumption of Homogeneity of Variances}

As displayed in Table IV, the results of Levene's tests were non-significant $(F(2,87)=.1 .68, \mathrm{P}>.05)$ meaning that there was not any significant difference between the variances of the groups.

TABLE IV.

TESTING HOMOGENEITY OF VARIANCES IN POST-TEST SCORES

\begin{tabular}{llll}
\hline $\mathrm{F}$ & df1 & df2 & Sig. \\
\hline 1.683 & 2 & 87 & .192 \\
\hline
\end{tabular}

\section{B. Linear Relationship between the Covariate and Dependent Variable}


The linear relationship between the covariate (pre-test) and dependent variable (post-test) was checked through scatter plots drawn for each group. For this assumption to be met, the spread of dots should fall on the diagonal showing no marked rise-and-fall patterns.

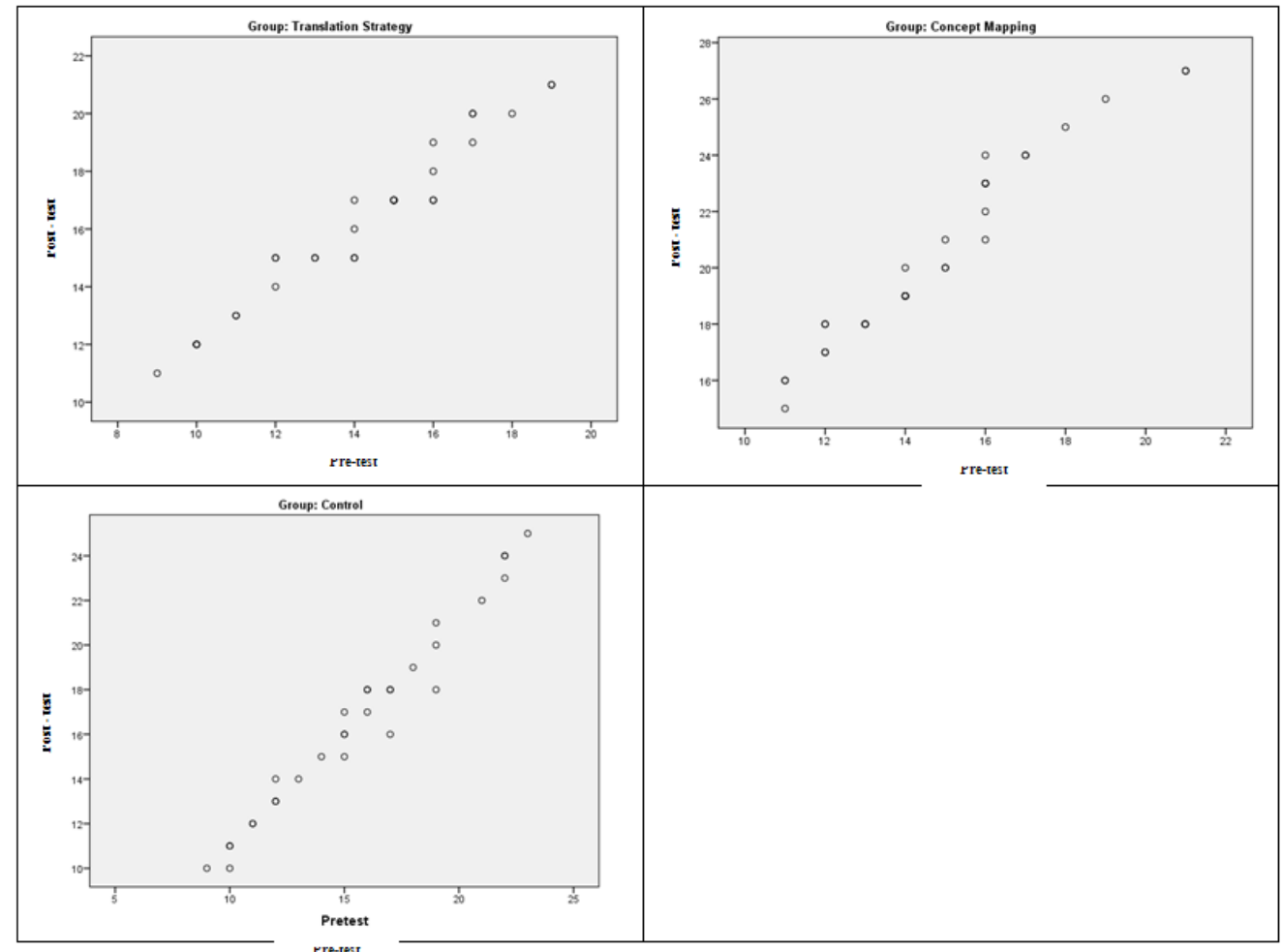

Figure 1. Scatter Plot Representing Testing Assumption of Linearity

\section{Assumption of Reliability of the Covariate}

The reliability of the pre-test as computed by KR-21 formula turned out to be 0.68 , which can be considered as acceptable.

\section{Assumption of Homogeneity of Regression Slope}

The homogeneity of regression slopes can be probed by a single scatter plot containing all groups. As displayed in Scatter Plot 2 the regression slopes all showed the same trend. These results indicated that the three groups showed homogeneous regression slopes.

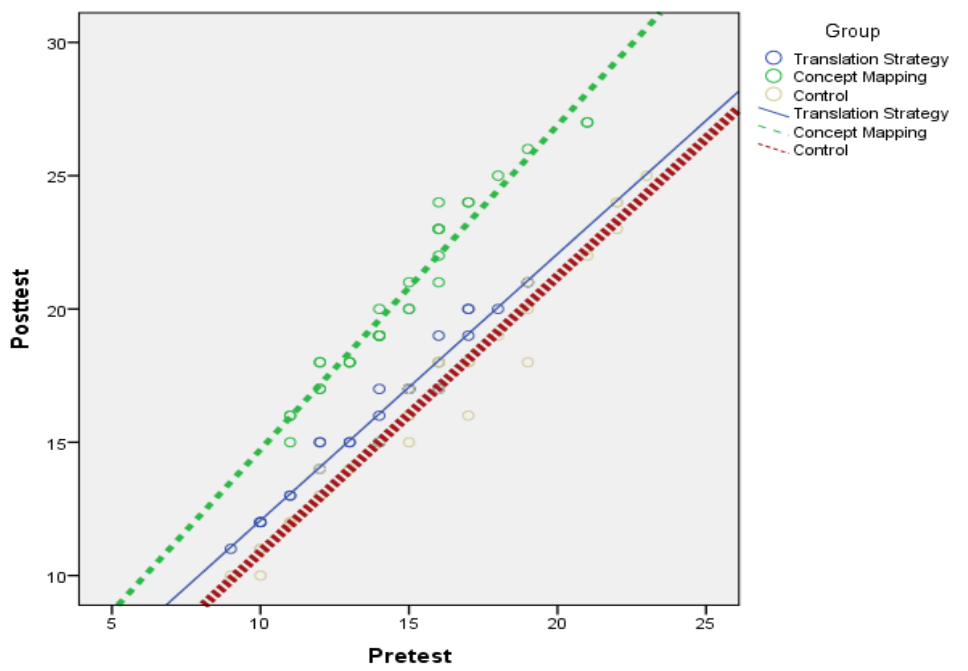

Figure 2. Scatter Plot Representing Testing Assumption of Homogeneity Regression Slope

An analysis of covariance (ANCOVA) was run to examine any likely influence of teaching strategies on reading comprehension ability of the learner. Since the sig value corresponding the group in Table V is far below the alpha level 
of 0.05 , it can be claimed that different interventions have been able to influence the reading comprehension ability of the learners differently $(\mathrm{F}(2,86)=312.94, \mathrm{P}<.05$, Partial $\eta 2=.87)$.

TABLE V.

ANCOVA ON THE POST-TEST SCORES

\begin{tabular}{llllll}
\hline Source & $\begin{array}{l}\text { Type III Sum of } \\
\text { Squares }\end{array}$ & df & Mean Square & F & Sig. \\
\hline Pre-test & 1056.996 & 1 & 1056.996 & 1785.742 & .000 \\
Group & 370.470 & 2 & 185.235 & 312.945 & .000 \\
Error & 50.904 & 86 & .592 & & .874 \\
Total & 29875.000 & 90 & & & \\
\hline
\end{tabular}

To find out where the exact differences lie, the post-hoc comparison tests was run to compare the groups two by two (Table VI below) in order to probe the three null-hypotheses raised in this study. The results indicated that:

A: There was a significant difference between the mean scores of the Concept Mapping $(\mathrm{M}=20.53)$ and control group $(\mathrm{M}=15.94 ; \mathrm{MD}=4.59, \mathrm{P}<.05)$. Based on these results, it was concluded that the first null-hypothesis stating that "concept mapping strategy did not improve reading comprehension ability of Iranian L2 learners" was rejected. The Concept Mapping group outperformed the control group on the post-test of reading comprehension after controlling for possible effects of the pre-test.

TABLE VI.

POST-HOC COMPARISONS

\begin{tabular}{|c|c|c|c|c|c|c|}
\hline \multirow[t]{2}{*}{ (I) Group } & \multirow[t]{2}{*}{ (J) Group } & \multirow[t]{2}{*}{$\begin{array}{l}\text { Mean Difference } \\
(\mathrm{I}-\mathrm{J})\end{array}$} & \multirow[t]{2}{*}{ Std. Error } & \multirow[t]{2}{*}{ Sig.b } & \multicolumn{2}{|c|}{$\begin{array}{l}\text { 95\% Confidence Interval for } \\
\text { Differenceb }\end{array}$} \\
\hline & & & & & $\overline{\text { Lower Bound }}$ & Upper Bound \\
\hline Translation & Control & $.935^{*}$ & .195 & .000 & .460 & 1.410 \\
\hline \multirow[t]{2}{*}{ Concept Mapping } & Translation & $3.655^{*}$ & .196 & .000 & 3.178 & 4.133 \\
\hline & Control & $4.591 *$ & .186 & .000 & 4.137 & 5.044 \\
\hline
\end{tabular}

*. The mean difference is significant at the .05 level.

B: There was a significant difference between the mean scores of the Translation Strategy $(\mathrm{M}=16.87)$ and control group $(\mathrm{M}=15.94 ; \mathrm{MD}=.93, \mathrm{P}<.05)$. Based on these results, it was concluded that the second null-hypothesis as "translation strategy did not improve reading comprehension ability of Iranian L2 learners" was rejected. The Translation Strategy group outperformed the control group on the post-test of reading comprehension after controlling for possible effects of the pre-test.

C: There was a significant difference between the mean scores of the Concept Mapping $(\mathrm{M}=20.53)$ and Translation Strategy group $(\mathrm{M}=16.87 ; \mathrm{MD}=3.65, \mathrm{P}<.05)$. Based on these results, it was concluded that the third null-hypothesis as "reading comprehension ability of the L2 learners did not differentially improve using concept mapping and translation strategies" was rejected. The Concept Mapping group outperformed the Translation Strategy group on the post-test of reading comprehension after controlling for possible effects of the pre-test.

\section{DISCUSSION AND CONCLUSIONS}

The current study used two strategy-based teaching interventions and examined the reading comprehension development of two groups comparing them against the performance of a third control group. The findings revealed that integrating concept mapping strategies in the process of reading instruction might help facilitate doing reading task and consequently assist retention. It seems that using concept maps can be more promising compared to even translation perhaps because it provokes learners to develop deeper insight into the content as well as linguistic forms assumed to play a role in making sense out of a written text.

The second finding of this research revealed that the translation strategy group outperformed the control group on the post-test of reading comprehension. This also represented that instructing reading through administration of phases of text translation might have the potential to facilitate comprehension. This finding is also supported by the previous research, though most of the researches conducted have not compared the impact of translation strategy training with other strategies used in teaching reading comprehension including concept mapping. Bassnett (1998) argued that translation strategies could increase the learner (translator)'s understanding of the text. Mahmoud (1998) also researched the impact of translation in FL reading comprehension and came to know that translation strategies were a neglected didactic procedure in this regard. He then suggested employing translation as a valuable tool in teaching the foreign language reading comprehension. Azizinezhad (2006) investigated the teachability of translation strategies and came to know that translation strategies could be taught to the learners and this really could help the low level learners come up with sound understanding of the materials they cover, though it could be considered a bit time-consuming. Liao (2006) studied the EFL learners' beliefs about and strategy use of translation in English learning and found that majority of the learners believed that translation strategies could help them improve their understanding of the second / foreign language texts and developing their foreign language. 
Another finding of the study emerging from post hoc comparisons of the group performances in posttest depicted that use of concept mapping strategy yielded better results compared to translation strategy The findings of this study concerning the positive impact of concept mapping strategies on the EFL learners' reading comprehension development support some previous studies (e.g., Clayton, 2006; Deylam Salehi, etal, 2013; Douma, etal, 2009; Edwards, et al, 1983; Gómez, et al, 2011; Grab, 2002; Hadley, 2003).Our findings also corroborate Kalhor and Shakibaei's (2012) finding that categorical facilitation, which is a verbal input device within the body of concept mapping, positively affects L2 vocabulary learning and reading comprehension development in a classroom setting.

In conclusion, the results of the study suggest that use of concept mapping and translation strategies have a direct impact on students' reading comprehension ability and concept mapping seems to be even more beneficial in promoting L2 reading comprehension.

\section{REFERENCES}

[1] Abdrabou, Abdulrahman, A. (2003). Implications for the teaching of English as a foreign language. Yemen Times, 1-4. http://yementimes.com (Last: October 2007).

[2] Aghaie, R., \& Zhang, L. J. (2012). Effects of explicit instruction in cognitive and metacognitive reading strategies on Iranian EFL students' reading performance and strategy transfer. Instructional Science, 40(6), 1063-1081.

[3] Antoniou, F., \&Souvignier, E. (2007). Strategy instruction in reading comprehension: An intervention study for students with learning disabilities. Learning Disabilities: A Contemporary Journal, 5, 41-57.

[4] Amiri, M., \&Maftoon, P. (2010). Awareness of reading strategies among Iranian high school students (pp.6782-92). Proceedings of EDULEARN10 Conference, 5th $-7^{\text {th }}$ July 2010, Barcelona, Spain. ISBN:978-84-613-9386-2 006782.

[5] Avand, A. (1994). The effect of translation on reading comprehension of ESP learners. Tehran: Tarbiat Modares University.

[6] Azizinezhad, M. (2006). Is translation teachable? Translation Journal, 10 (2), http://accurapid.com/journal/36edu.htm (Last: October 2007).

[7] Bassnett, S. (1998). Researching translation studies. In P. Bush, \& K. Malmkjaer (Eds.) Rimbaud's rainbow: Literary translation in higher education (pp. 105-118). Amsterdam: John Benjamins.

[8] Brown, H.D. (2000). Principles of language learning and teaching. Longman: Pearson Education Co.

[9] Carter, R.M. \& Nunan, D. (Eds.). (2001). The Cambridge guide to teaching English to speakers of other languages. Cambridge: Cambridge University Press.

[10] Chamot, A.U. (1987). The learning strategies of ESL students. In A.L. Wenden, \& J. Rubin (Eds.), Learner strategies in language learning (pp. 71-83). Englewood Cliffs, NJ: Prentice-Hall.

[11] Chamot, A.U., \& Kupper, L. (1989). Learning strategies in foreign language instruction. Foreign Language Annals, 22, 13-24.

[12] Chamot, A. U. (2005). Language learning strategy instruction: Current issues and research. Annual Review of Applied Linguistics, 25, 112-130.

[13] Chang, K.E., Sung, Y.T., \& Chen, I. D. (2002).The effect of concept mapping to enhance text comprehension and summarization. The Journal of Experimental Education, 71(1), 5-23.

[14] Chen, Z. C. (1998). Teaching by using the strategy of concept mapping on the effect of elementary school students' learning scientific subjects. Journal of Education \& Psychology, 21, 107-128.

[15] Chularut, P., \& DeBacker, T.K. (2004). The influence of concept mapping on achievement, self regulation and self-efficacy in students of English as a second language. Contemporary Educational Psychology, 29,248 -263.

[16] Clayton, H.L. (2006). Concept mapping: An effective, active teaching-learning method. Nursing Education Perspective, 27, 197-203.

[17] Cohen, A.D., \& Brooks-Carson, A. (2001). Research on direct versus translated writing: Students' strategies and their results. The Modern Language Journal, 85(2), 169-188.

[18] Cook, V. (2001). Second language learning and language teaching. London: Edvard Arnold.

[19] Deylam Salehi, A., Jahandar, S., \&Khodabandehlou, M. (2013). The impact of concept mapping on EFL student's reading comprehension. Indian Journal of Fundamental and Applied Life Sciences, 3(3), 241-250.

[20] Douma, M., Ligierko, G., \& Romano, J. (2009). Creating online mind maps and concept maps.25 ${ }^{\text {th }}$ Annual Conference on Distance Teaching and Learning, 1-8.

[21] Edwards, J., \& Fraser, K. (1983). Concept Maps as reflectors of conceptual understanding. Research in Science Education, 13, $19-26$.

[22] Ellis, R. (1985). Understanding second language acquisition. Oxford: Oxford University Press.

[23] Gómez, F. A. A., López, D. C., \& Marin, L. F. G. (2011). Reading comprehension in face-to-face and web-based modalities: graduate students' use of reading and language learning strategies in EFL. Colombian Applied Linguistics Journal, 13(2), 11-28.

[24] Hay, B.D., \& Kinchin, M.L. (2006). Using concept maps to reveal conceptual typologies. Education \& Training, 48, $127-142$.

[25] Hsieh, L. T. (2000). The effects of translation on English vocabulary and reading learning, paper presented at the ninth international symposium on English teaching. Taipei, Taiwan: ROC.

[26] Jalilifar, A. (2010). The effect of cooperative learning techniques on college students' reading comprehension. System, 38, $96-$ 108.

[27] Kalhor, M., \& Shakibaei, G. (2012). Teaching reading comprehension through concept map. Life Science Journal, 9(4), 725731.

[28] Kaplan, R. B. (Ed.). (2002). The Oxford handbook of applied linguistics. Oxford: Oxford University Press.

[29] Liao, P. S. (2006). EFL learners' beliefs about and strategy use of translation in English learning. RELC Journal, 37(2), 191215.

[30] Khajavi \& Ketabi(2012). Influencing EFL Learners' Reading Comprehension and Self-efficacy Beliefs: The Effect of Concept Mapping Strategy. http://www.atriumlinguarum.org/. 
[31] Mahmoud, Abdulmoneim, M. (1998). Translation in FL reading comprehension: A neglected didactic procedure. In K. Malmkjaer (ed.) Translation and language teaching. Manchester: St. Jerome.

[32] Maleki, M., \& Dabbaghi, A. (2013). The influences of concept mapping strategy on reading comprehension of those students challenging in studying invalid books at some high schools. MJAL, 5(2), 101-127.

[33] Moreira, M. M., \& Moreira, S. M. (2011). Meaningful learning: use of concept maps in foreign language education. Aprendizagem Significativaem Revista/Meaningful Learning Review, VI(2), 64-75.

[34] Nunan, D. (1999). Second language teaching \& learning. USA: Heinle \& Heinle Publishers.

[35] O’Malley, J.M., Chamot, A.U., Stewner-Manzanares, G., Kupper, L., \& Russo, R.P.(1985a). Learning strategies used by beginning and intermediate ESL students. Language Learning, 35, 21-46.

[36] O’Malley, J.M., Chamot, A.U., Stewner-Manzanares, G., Kupper, L., \& Russo, R.P. (1985b). Learning strategy applications with students of English as a second language. TESOL Quarterly, 19, 557-84.

[37] Salehi, Jahandar, \& Khodabandehlou( 2013). The Impact of Concept Mapping on EFL Student's Reading Comprehension. Indian Journal of Fundamental and Applied Life Science, 3 (3), pp.241-250.

[38] Shimerda, T.A. (2007). Concept mapping: A technique to aid meaningful learning in business and accounting education. Indian Journal of Economics and Business, 6, 117-124.

[39] Snead, D., \& Snead, W. (2004). Concept mapping and science achievement of middle grade student. Journal of Research in Childhood Education, 18(4), 306-320.

[40] Talebinejad, M., \&Mousapour Negari, G. (2007). The effect of explicit teaching of concept mapping in expository writing on EFL students' self-regulation. Linguistics Journal, 2, 69 -90.

[41] Vakilifard, A., \& Armand, F. (2006). The effects of concept mapping on second language learners' comprehension of informative text. Proceedings of the second international conference on concept mapping, San José, Costa Rica.

[42] Wallace, J., \&Mintzes, J. (1990). The concept map as a research tool: Exploring conceptual change in biology. Journal of Research in Science Teaching, 27(10), 1033-1052.

[43] Yağmurşahin, E. (2013).The effect of concept maps on reading comprehension skills of elementary school students working outdoors. World Applied Sciences Journal, 24 (5), 588-593.

Mehran Davaribina is an assistant professor of ELT at Islamic Azad University Ardabil Branch in Iran. He has been teaching different courses for M.A. and PhD students for about twelve years. His research interests are theories of second language le arning and teaching, writing ability, and applied linguistics.

Shahram Esfandiari Asl is an English language teacher. He is currently a PhD candidate of ELT at Islamic Azad University Ardabil Branch in Iran. His research interests include second language learning and teaching, form-focused instruction, feedback types, and reading comprehension. 